\title{
Adapting the Pour-through Medium Extraction Method to Phalaenopsis Grown in Sphagnum Moss
}

\author{
Huan-Ying Yao \\ Department of Horticulture, National Taiwan University, 1 Roosevelt Road, \\ Sec. 4, Taipei 10617, Taiwan

\section{Ren-Shih Chung and Sheng-Bin Ho \\ Department of Agricultural Chemistry, National Taiwan University, Taipei 10617, Taiwan}

\author{
Yao-Chien Alex Chang ${ }^{1}$ \\ Department of Horticulture, National Taiwan University, 1 Roosevelt Road, \\ Sec. 4, Taipei 10617, Taiwan
}

Additional index words. soilless medium, substrate, EC, $\mathrm{pH}$, press method

\begin{abstract}
Sphagnum moss, which has very different chemical and physical characteristics compared with other soilless media, is commonly used as a substrate to grow Phalaenopsis in countries such as Japan and Taiwan. Pour-through (PT) is a nondestructive, effective, and convenient medium extraction method developed for peat-based media. To know if PT can be applied to sphagnum moss and to set up a standard procedure, experiments were conducted to test the effects of volume and electrical conductivity (EC) of the displacing solution and the timing of leachate collection on leachate properties. Results demonstrated that applying distilled water with a volume less than $70 \mathrm{~mL}$ to $10.5-\mathrm{cm}$ pots $1 \mathrm{~h}$ after fertigation did not influence leachate EC and pH. Applying displacing solution with EC between 0.001 and $0.93 \mathrm{dS} \cdot \mathrm{m}^{-1}$ $1 \mathrm{~h}$ after fertigation did not affect leachate $\mathrm{EC}$ or $\mathrm{pH}$. Thus, in theory, a variety of solutions may be used for displacement. Leachate properties were found to remain consistent when collected between 20 and 160 min after fertigation. These results demonstrated that PT can be successfully used in Phalaenopsis cultivation with sphagnum moss. Furthermore, substrate EC obtained by PT extraction was highly correlated with that by the press method, confirming that PT is a feasible medium extraction method for sphagnum moss in Phalaenopsis cultivation.
\end{abstract}

Medium solution testing is a precise way to monitor the real nutrition status of the rhizosphere with which plant roots intimately take part in exchanging substances. Monitoring the medium solution would thus help in timely adjustment of the fertilization program. Bunt (1986) classified chemical analyses of soilless media into suspensions, saturated media extracts (SME), and displaced soil solution methods; 2 water: 1 substrate (v/v) suspension (Sonneveld, 1990), the SME method (Warncke, 1986), and pour-through (PT) extraction (Wright, 1986; Yeager et al., 1983) are the most commonly used medium extraction methods in the three categories, respectively. The procedure of PT described by Wright (1986) is as follows: 1)

Received for publication 1 July 2008. Accepted for publication 26 Aug. 2008.

Financial support was provided by the Council of Agriculture, Executive Yuan, Taiwan (97AS1.2.1-ST-a1).

This study is a portion of a thesis submitted by Huan-Ying Yao in fulfilling a Master of Science degree requirement.

${ }^{1}$ To whom reprint requests should be addressed; e-mail alexchang@ntu.edu.tw ensure that the moisture level of the medium is at or near its water-holding capacity; 2) add a sufficient amount of distilled water to the surface of the container so that $\approx 50 \mathrm{~mL}$ of leachate is accumulated; and 3) analyze the leachate collected within $24 \mathrm{~h}$. Compared with other medium extraction methods, PT is much faster to execute and does not require costly equipment. Also, PT does not require physical removal of medium from the container, which can disrupt the root system. It has been used widely on peat-based and barkbased soilless media in laboratories and in nurseries. However, medium testing is rarely performed by Phalaenopsis growers in Japan and Taiwan possibly as a result of the unique chemical and physical characteristics of the substrate - sphagnum moss. Since June 2004, growers in the United States have been allowed to import Phalaenopsis plants grown in sphagnum moss from Taiwan. By importing mature Phalaenopsis in growing medium, the U.S. growers could directly apply cool-temperature forcing without replanting, which resulted in a great saving of labor, potting materials, and greenhouse overhead as well as a faster growth recovery than that of bare-root plants. There is thus a need for a better understanding of the characteristics of sphagnum moss and its fertilization management.

Sphagnum moss is a group of mosses belonging to the Sphagnum genus and could become sphagnum peatmoss after decomposing for years in a wet and cold environment. Dead cells of sphagnum moss are large in volume with thin but firm cell walls, which are excellent for transmitting water and holding shape (Puustjarvi, 1977). These characteristics make it an ideal substrate to retain water and air for epiphytic orchids. The airfilled porosity $(\mathrm{v} / \mathrm{v})$ of sphagnum moss is easily influenced by the bulk density with test data exhibiting a range of $15 \%$ to $26 \%$ under general conditions (Hwang and Jeong, 2007; Yao and Chang, unpublished data). The airfilled porosity of peatmoss $(8.1 \%$ when moisture is at container capacity) is much lower than that of sphagnum moss, whereas bark has a similar air-filled porosity $(20 \%$; Nelson, 2003) as sphagnum moss. The cation exchange capacity (CEC) of sphagnum moss, which ranges from 26 to $120 \mathrm{meq} / 100 \mathrm{~g}$ as the $\mathrm{pH}$ of the substrate increases from 3 to 7 (Kubota et al., 1993), is also higher than that of both bark ( 8 to $60 \mathrm{meq} / 100 \mathrm{~g}$ ) and peatmoss ( 7 to $13 \mathrm{meq} / 100 \mathrm{~g}$; Nelson, 2003). With properties of both high air-filled porosity and high CEC, the feasibility of applying PT to sphagnum moss is uncertain. The objectives of this study were, first, to ascertain whether PT could be adapted to Phalaenopsis cultivation with sphagnum moss and, second, to develop a standard procedure once feasibility is proved.

\section{Materials and Methods}

Plant materials. Vegetatively propagated Phalaenopsis Sogo Yukidian 'V3' plants, grown in sphagnum moss in $8.5-\mathrm{cm}$ pots or $4.5-\mathrm{cm}$ pots, were purchased and transplanted into $10.5-\mathrm{cm}$ pots $(0.75 \mathrm{~L})$ or $8.5-\mathrm{cm}$ pots $(0.35 \mathrm{~L})$, respectively. Sphagnum moss from Chile was used as potting medium and was immersed in water overnight before transplanting. The bulk density of sphagnum moss in planted pots was $\approx 50 \mathrm{mg} \cdot \mathrm{cm}^{-3}$. Plants were then grown in a greenhouse with a pad and fan system and were fertigated with a 20N-8.7P-16.6K fertilizer (Peters Professional 20-20-20; The Scotts Co., Marysville, $\mathrm{OH})$ at $200 \mathrm{mg} \cdot \mathrm{L}^{-1} \mathrm{~N}$ every 2 to 3 weeks. Unless otherwise noted, each experiment used either newly transplanted Phalaenopsis or plants that have been grown in the greenhouse for 4 to 6 weeks but were leached with a substantial amount of reverse osmosis (RO) water $(\approx 0.5 \mathrm{~L} /$ pot $)$ before the experiment started.

Effect of volume of displacing water applied. Plants (in 10.5-cm pots) were fertigated with a $20 \mathrm{~N}-8.7 \mathrm{P}-16.6 \mathrm{~K}$ fertilizer at $200 \mathrm{mg} \cdot \mathrm{L}^{-1} \mathrm{~N}$. Different volumes of $\mathrm{RO}$ water were then applied to the surface of the substrate $1 \mathrm{~h}$ after fertigation, the volume of water applied ranging from 40 to $120 \mathrm{~mL}$ (as shown in Table 1). Leachate was collected and tested for $\mathrm{pH}$ and electrical conductivity (EC) by a pH and EC meter (IQ170; 
Table 1. Leachate electrical conductivity (EC) and $\mathrm{pH}$ of sphagnum moss as affected by displacing water volumes (10.5-cm pots).

\begin{tabular}{lccc}
\hline $\begin{array}{l}\text { Volume } \\
\begin{array}{l}\text { applied } \\
(\mathrm{mL})\end{array}\end{array}$ & $\begin{array}{c}\text { Volume } \\
\text { collected }^{\mathrm{z}} \\
(\mathrm{mL})\end{array}$ & $\begin{array}{c}\text { Leachate } \\
\text { EC } \\
\left(\mathrm{dS} \cdot \mathrm{m}^{-1}\right)\end{array}$ & $\begin{array}{c}\text { Leachate } \\
\mathrm{pH}\end{array}$ \\
\hline 40 & 38 & $0.62 \mathrm{a}^{\mathrm{y}}$ & $3.80 \mathrm{ab}$ \\
50 & 46 & $0.60 \mathrm{ab}$ & $3.89 \mathrm{ab}$ \\
60 & 54 & $0.61 \mathrm{ab}$ & $3.83 \mathrm{ab}$ \\
70 & 64 & $0.59 \mathrm{~b}$ & $3.84 \mathrm{ab}$ \\
80 & 70 & $0.60 \mathrm{ab}$ & $3.83 \mathrm{ab}$ \\
90 & 77 & $0.59 \mathrm{ab}$ & $3.75 \mathrm{~b}$ \\
100 & 86 & $0.56 \mathrm{c}$ & $3.87 \mathrm{ab}$ \\
110 & 100 & $0.54 \mathrm{c}$ & $3.90 \mathrm{ab}$ \\
120 & 113 & $0.53 \mathrm{c}$ & $3.91 \mathrm{a}$ \\
\hline
\end{tabular}

${ }^{\mathrm{z}}$ Linear regression of displacing water volumes $(\mathrm{x})$ versus leachate volumes $(\mathrm{y}): \mathrm{y}=0.326+0.894 \mathrm{x}$; $r^{2}=0.99, P<0.0001$.

${ }^{\mathrm{y}}$ Means in the same column followed by a different letter are significantly different at $P \leq 0.05$ by least significant difference test $(n=20)$.

IQ Scientific Instruments, Carlsbad, CA), and the volume of leachate collected was also measured. The experiment was conducted in a completely randomized design with 20 single-plant replications per treatment. Because the volume of water applied is an important factor for the accuracy of PT, the experiment was repeated four times, each time with a new batch of plants and sphagnum moss. Concentrations of ions in the leachate were further determined in one of the repeated experiments. Concentrations of $\mathrm{NO}_{3}{ }^{-}-\mathrm{N}$ and $\mathrm{NH}_{4}{ }^{+}-\mathrm{N}$ were measured by the magnesium oxide-Devarda alloy method (Page et al., 1986). Concentration of phosphorus was analyzed by molybdenum-blue spectrophotometry (Murphy and Riley, 1962), and concentrations of potassium, calcium, and magnesium were measured by inductively coupled plasma spectrometry (ICP-AES; Optima 2000DV, Perkin Elmer, Wellesley, MA).

Another experiment was conducted to test the suitable volume of displacing water for $8.5-\mathrm{cm}$ pots. After being transplanted into $8.5 \mathrm{-cm}$ pots, plants were grown in a greenhouse for 2 months and fertilized two times with a $15 \mathrm{~N}-2.2 \mathrm{P}-12.5 \mathrm{~K}$ fertilizer (Peters Excel 15-5-15 Cal-Mag; The Scotts Co.) at $200 \mathrm{mg} \cdot \mathrm{L}^{-1} \mathrm{~N}$ before the experiment began. One hour after the third fertilization, RO water with a volume from 40 to $70 \mathrm{~mL}$ was applied, and the leachate was tested for $\mathrm{pH}$ and EC. The volume of leachate was also measured. The experiment was arranged in a completely randomized design with 18 single-plant replications per treatment.

Effect of electrical conductivity of the applied displacing solution. Plants (in 10.5$\mathrm{cm}$ pots) were fertigated with a $20 \mathrm{~N}-8.7 \mathrm{P}-$ $16.6 \mathrm{~K}$ fertilizer at $200 \mathrm{mg} \cdot \mathrm{L}^{-1} \mathrm{~N}$ and then seven solutions with different ECs were applied $1 \mathrm{~h}$ after fertigation. The volume of the displacing solution was $60 \mathrm{~mL}$ based on the results from prior experiments. The displacing solutions included double-distilled water, Taisun Pure Water (Taisun Enterprise Co., Taipei, Taiwan), tap water, Y.E.S. Mineral Water (Yes! Co., Yilan, Taiwan), and 100,200 , and $5000 \mathrm{mg} \cdot \mathrm{L}^{-1} \mathrm{~N}$ of a $20 \mathrm{~N}-8.7 \mathrm{P}$ $16.6 \mathrm{~K}$ fertilizer. Leachate was then collected and tested for $\mathrm{pH}$ and EC. Each treatment had 15 single-plant replications in a completely randomized design.

Effect of leachate collection time. Three independent experiments were carried out. In the first experiment, plants (in $10.5-\mathrm{cm}$ pots) were fertigated with a $15 \mathrm{~N}-2.2 \mathrm{P}-12.5 \mathrm{~K}$ fertilizer at $200 \mathrm{mg} \cdot \mathrm{L}^{-1} \mathrm{~N}$, and $60 \mathrm{~mL}$ RO water was applied to displace the medium solution $0,20,40,60,80,100,120,140$, and $160 \mathrm{~min}$ after fertigation. Sampling time at Minute 0 was actually performed 0 to $1 \mathrm{~min}$ after fertigation because of technical difficulties. In the second and third experiments, plants were fertigated with a $20 \mathrm{~N}-8.7 \mathrm{P}-16.6 \mathrm{~K}$ fertilizer at $200 \mathrm{mg} \cdot \mathrm{L}^{-1} \mathrm{~N}$ and leachate was sampled at $0,1,2,3,4,5$, and $6 \mathrm{~d}$ and $0,5,10$, 15,20 , and $25 \mathrm{~d}$ after fertigation, respectively. Day 0 sampling was performed $1 \mathrm{~h}$ after fertigation, and samplings on other days were done at a similar hour on the indicated day. The substrate became unsaturated $\approx 10 \mathrm{~d}$ after fertigation; an appropriate amount of distilled water was added to the substrate surface $1 \mathrm{~h}$ before PT sampling to saturate the substrate without any leaching occurring. The experiment was arranged in a completely randomized design with 20 single-plant replications per treatment.

Comparison of substrate electrical conductivity as tested by pour-through and by press. Because the principle of PT is like adding water to the top of a sponge, which displaces the water in the sponge, we compared it with an authentic medium testing method called the press extraction method
(PE), which can also be applied to sphagnum moss. The press method was invented for plugs in which the medium solution is squeezed out by means of a simple "press" (Scoggins et al., 2001). Because we used soft plastic pots as growing containers, the PE method was modified. The squeezing pressure was applied to the pot edges by two hands in this experiment until $\approx 30 \mathrm{~mL}$ of leachate was collected. After being transplanted and placed in the greenhouse for $\approx 2$ weeks, Phalaenopsis in $10.5-\mathrm{cm}$ pots were randomly divided into two groups of 82 plants each, and both were fertigated with different concentrations of a $20 \mathrm{~N}-8.7 \mathrm{P}$ $16.6 \mathrm{~K}$ fertilizer. Concentrations of the 82 fertilizer solutions applied ranged from 0 to $400 \mathrm{mg} \cdot \mathrm{L}^{-1} \mathrm{~N}$ and resulted in a fertilizer EC ranging from 0 to $1.6 \mathrm{dS} \cdot \mathrm{m}^{-1}$. The substrate EC was then tested, one group by PT and the other by PE. The obtained data were subjected to correlation analysis.

\section{Results and Discussion}

Effect of volume of displacing water applied. The four repeated experiments for $10.5-\mathrm{cm}$ pots resulted in a similar trend; therefore, only results from two of the repeated experiments are presented. The volume of leachate collected increased proportionally with the volume of water applied to sphagnum moss at container moisture capacity (Tables 1 and 2). Increasing the volume of water applied from 40 to $70 \mathrm{~mL}$ did not result in different levels of extract EC and $\mathrm{pH}$ (Tables 1 and 2); concentrations of leachate $\mathrm{NO}_{3}{ }^{-} \mathrm{N}$, phosphorus, potassium, calcium, and magnesium under treatments of 40 to $60 \mathrm{~mL}$ displacing water were also consistent (Table 2). Electrical conductivity and some mineral ions tested in the experiments decreased slightly when more than 60 $\mathrm{mL}$ of water was applied (Tables 1 and 2), indicating leachate was diluted by overapplication of displacing water. Because the volume of leachate collected in the $60 \mathrm{~mL}$ displacing water treatment was $\approx 50 \mathrm{~mL}$ (Tables 1 and 2), which fits most with the PT procedure recommended by Wright (1986), we therefore suggest using $60 \mathrm{~mL}$ displacing water as a standard procedure in applying PT on sphagnum moss for $\mathrm{Pha}$ laenopsis cultivation in $10.5-\mathrm{cm}$ pots. The

Table 2. Leachate status of sphagnum moss as affected by displacing water volumes (10.5-cm pots).

\begin{tabular}{|c|c|c|c|c|c|c|c|c|c|}
\hline $\begin{array}{l}\text { Volume } \\
\text { applied } \\
(\mathrm{mL})\end{array}$ & $\begin{array}{l}\text { Volume } \\
\text { collected }^{\mathrm{z}} \\
(\mathrm{mL})\end{array}$ & $\begin{array}{c}\text { Leachate } \\
\mathrm{EC}\left(\mathrm{dS} \cdot \mathrm{m}^{-1}\right)\end{array}$ & $\begin{array}{l}\text { Leachate } \\
\text { pH }\end{array}$ & $\begin{array}{l}\mathrm{NH}_{4}^{+}-\mathrm{N} \\
\left(\mathrm{mg} \cdot \mathrm{L}^{-1}\right)\end{array}$ & $\begin{array}{l}\mathrm{NO}_{3}{ }^{-}-\mathrm{N} \\
\left(\mathrm{mg} \cdot \mathrm{L}^{-1}\right)\end{array}$ & $\begin{array}{l}\text { Phosphorus } \\
\left(\mathrm{mg} \cdot \mathrm{L}^{-1}\right)\end{array}$ & $\begin{array}{l}\text { Potassium } \\
\left(\mathrm{mg} \cdot \mathrm{L}^{-1}\right)\end{array}$ & $\begin{array}{l}\text { Calcium } \\
\left(\mathrm{mg} \cdot \mathrm{L}^{-1}\right)\end{array}$ & $\begin{array}{l}\text { Magnesium } \\
\left(\mathrm{mg} \cdot \mathrm{L}^{-1}\right)\end{array}$ \\
\hline 40 & 34 & $0.64 \mathrm{a}^{\mathrm{y}}$ & $4.01 \mathrm{bc}$ & $19.7 \mathrm{a}$ & $19.8 \mathrm{a}$ & $31.9 \mathrm{a}$ & $62.8 \mathrm{ab}$ & $5.0 \mathrm{ab}$ & $4.9 \mathrm{abc}$ \\
\hline 50 & 43 & $0.63 \mathrm{ab}$ & $3.99 \mathrm{c}$ & $18.0 \mathrm{ab}$ & $19.7 \mathrm{a}$ & $31.1 \mathrm{ab}$ & $65.4 \mathrm{a}$ & $5.6 \mathrm{a}$ & $5.3 \mathrm{a}$ \\
\hline 60 & 51 & $0.62 \mathrm{~b}$ & $3.99 \mathrm{bc}$ & $16.5 \mathrm{bc}$ & $19.8 \mathrm{a}$ & $31.3 \mathrm{ab}$ & $65.3 \mathrm{a}$ & $5.4 \mathrm{a}$ & $5.2 \mathrm{ab}$ \\
\hline 70 & 56 & $0.62 \mathrm{ab}$ & $3.99 \mathrm{c}$ & $16.7 \mathrm{bc}$ & $18.2 \mathrm{ab}$ & $30.0 \mathrm{bc}$ & $62.0 \mathrm{abc}$ & $5.4 \mathrm{a}$ & $5.1 \mathrm{ab}$ \\
\hline 80 & 64 & $0.61 \mathrm{c}$ & $3.98 \mathrm{c}$ & $16.9 \mathrm{bc}$ & $18.0 \mathrm{ab}$ & $28.8 \mathrm{c}$ & $59.6 \mathrm{bc}$ & $4.2 \mathrm{bc}$ & $4.6 \mathrm{bc}$ \\
\hline 90 & 74 & $0.59 \mathrm{~cd}$ & $4.08 \mathrm{ab}$ & & & & & & \\
\hline 100 & 77 & $0.58 \mathrm{de}$ & $4.12 \mathrm{a}$ & $14.8 \mathrm{c}$ & $17.1 \mathrm{ab}$ & $28.7 \mathrm{c}$ & $57.0 \mathrm{c}$ & $4.4 \mathrm{bc}$ & $4.7 \mathrm{bc}$ \\
\hline 110 & 91 & $0.58 \mathrm{de}$ & $4.11 \mathrm{a}$ & & & & & & \\
\hline 120 & 106 & $0.58 \mathrm{e}$ & $4.12 \mathrm{a}$ & $16.5 \mathrm{bc}$ & $16.2 \mathrm{~b}$ & $26.2 \mathrm{~d}$ & $58.8 \mathrm{bc}$ & $3.9 \mathrm{c}$ & $4.4 \mathrm{c}$ \\
\hline
\end{tabular}

${ }^{\mathrm{z}}$ Linear regression of displacing water volumes $(\mathrm{x})$ versus leachate volumes $(\mathrm{y}): \mathrm{y}=-1.136+0.841 \mathrm{x} ; r^{2}=0.98, P<0.0001$.

${ }^{\mathrm{y}}$ Means in the same column followed by a different letter are significantly different at $P \leq 0.05$ by least significant difference test $(\mathrm{n}=20)$.

$\mathrm{EC}=$ electrical conductivity. 
volume is in a range safe from dilution effects and is also appropriate for comparing the results with other investigations that were carried out by collecting leachate at a volume of $50 \mathrm{~mL}$.

Among all the ions tested, $\mathrm{NH}_{4}{ }^{+}-\mathrm{N}$, appearing to be a more difficult cation to extract, was the only one diluted when $60 \mathrm{~mL}$ of water was applied compared with $40 \mathrm{~mL}$ (Table 2). When comparing the PT with the SME medium testing method on bark, both methods achieved higher extraction efficiency for $\mathrm{NO}_{3}{ }^{-} \mathrm{N}$ than for $\mathrm{NH}_{4}{ }^{+}-\mathrm{N}$ (Wright et al., 1990). The causes for this phenomenon are unclear; perhaps $\mathrm{NH}_{4}{ }^{+}-\mathrm{N}$ is bound strongly to the substrates. Despite the observed dilution of $\mathrm{NH}_{4}{ }^{-}-\mathrm{N}$, when focusing on all of the nutrients presented by EC levels, PT is still firmly believed to be an effective medium extracting method.

Results of the experiment to test for the appropriate volume of displacing water for $8.5-\mathrm{cm}$ pots showed an analogous trend with that of $10.5-\mathrm{cm}$ pot experiments (Tables $1-3$ ). Although leachate EC levels did not change when 30 to $60 \mathrm{~mL}$ of water was applied, leachate dilution was noted when more than $60 \mathrm{~mL}$ of water was poured (Table 3). Because the volume of displacing water proposed for $10.5-\mathrm{cm}$ pots $(60 \mathrm{~mL})$ was quite close to the amount at which dilution may occur in this experiment, a volume of $40 \mathrm{~mL}$ is therefore suggested as appropriate for $8.5-\mathrm{cm}$ pots.

The suggestion of $50 \mathrm{~mL}$ leachate collection came from the result for a 3-L container applied with $100 \mathrm{~mL}$ displacing water (Wright, 1986; Yeager et al., 1983); examiners tend to adjust the amount of displacing water when applying PT on smaller or larger containers. Tolman et al. (1990) applied 45 $\mathrm{mL}$ displacing water on a 0.5 -L pot with 1 peat: 1 perlite medium growing marigold. Wang (1998) collected $\approx 30 \mathrm{~mL}$ leachate when applying PT on a bark or 4 bark: 1 peat medium growing Phalaenopsis. On the other hand, Wright and Hinesley (1991) poured $350 \mathrm{~mL}$ displacing water and collected 100 to $150 \mathrm{~mL}$ leachate when examining the medium solution of an eastern redcedar grown with a 5 bark: 1 sand medium in a 20-L container. Because the Phalaenopsis used for this study were grown in comparatively smaller containers $(0.35$ to $0.75 \mathrm{~L})$, the

Table 3. Leachate electrical conductivity (EC) and $\mathrm{pH}$ of sphagnum moss as affected by displacing water volumes $(8.5-\mathrm{cm}$ pots).

\begin{tabular}{lccc}
$\begin{array}{l}\text { Volume } \\
\begin{array}{l}\text { applied } \\
(\mathrm{mL})\end{array}\end{array}$ & $\begin{array}{c}\text { Volume } \\
\text { collected } \\
(\mathrm{mL})\end{array}$ & $\begin{array}{c}\text { Leachate } \\
\mathrm{EC}\left(\mathrm{dS} \cdot \mathrm{m}^{-1}\right)\end{array}$ & $\begin{array}{c}\text { Leachate } \\
\mathrm{pH}\end{array}$ \\
\hline 30 & 28 & $1.18 \mathrm{a}^{\mathrm{y}}$ & $2.73 \mathrm{~b}$ \\
40 & 38 & $1.16 \mathrm{a}$ & $2.91 \mathrm{a}$ \\
50 & 49 & $1.18 \mathrm{a}$ & $2.76 \mathrm{~b}$ \\
60 & 56 & $1.14 \mathrm{a}$ & $2.70 \mathrm{~b}$ \\
70 & 64 & $1.08 \mathrm{~b}$ & $2.78 \mathrm{~b}$ \\
\hline
\end{tabular}

${ }^{\mathrm{z}}$ Linear regression of displacing water volumes $(\mathrm{x})$ versus leachate volumes $(\mathrm{y}): \mathrm{y}=2.007+0.900 \mathrm{x}$; $r^{2}=0.996, P<0.0001$.

${ }^{\mathrm{y}}$ Means in the same column followed by a different letter are significantly different at $P \leq 0.05$ by least significant difference test $(\mathrm{n}=18)$.

Table 4. Leachate electrical conductivity (EC) and $\mathrm{pH}$ of sphagnum moss as affected by displacing solution EC values.

\begin{tabular}{lcccc}
\hline Solutions applied & $\begin{array}{c}\text { EC of solution } \\
\text { applied }\left(\mathrm{dS} \cdot \mathrm{m}^{-1}\right)\end{array}$ & $\begin{array}{c}\mathrm{pH} \text { of solution } \\
\text { applied }\end{array}$ & $\begin{array}{c}\text { Leachate EC } \\
\left(\mathrm{dS} \cdot \mathrm{m}^{-1}\right)\end{array}$ & $\begin{array}{c}\text { Leachate } \\
\mathrm{pH}\end{array}$ \\
\hline Double distilled water & 0.00 & 6.50 & $0.73 \mathrm{~b}^{\mathrm{y}}$ & $3.51 \mathrm{a}$ \\
Taisun Pure Water & 0.00 & 7.33 & $0.70 \mathrm{~b}$ & $3.71 \mathrm{a}$ \\
Tap water & 0.09 & 7.48 & $0.70 \mathrm{~b}$ & $3.63 \mathrm{a}$ \\
Y.E.S. Mineral Water & 0.20 & 7.40 & $0.71 \mathrm{~b}$ & $3.46 \mathrm{a}$ \\
$100 \mathrm{mg} \cdot \mathrm{L}^{-1} \mathrm{~N}^{\mathrm{z}}$ & 0.51 & 6.60 & $0.64 \mathrm{~b}$ & $3.61 \mathrm{a}$ \\
$200 \mathrm{mg} \cdot \mathrm{L}^{-1} \mathrm{~N}^{\mathrm{z}}$ & 0.93 & 6.48 & $0.75 \mathrm{~b}$ & $3.52 \mathrm{a}$ \\
$5000 \mathrm{mg} \cdot \mathrm{L}^{-1} \mathrm{~N}^{\mathrm{z}}$ & 16.74 & 4.98 & $1.00 \mathrm{a}$ & $3.53 \mathrm{a}$ \\
\hline
\end{tabular}

${ }^{\mathrm{z}}$ Different concentrations of a $20 \mathrm{~N}-8.7 \mathrm{P}-16.6 \mathrm{~K}$ fertilizer (Peters 20-20-20).

${ }^{\mathrm{y}}$ Means in the same column followed by a different letter are significantly different at $P \leq 0.05$ by least significant difference test $(\mathrm{n}=15)$.

effectiveness of PT is more likely to be affected if a larger amount of displacing water is applied.

Effect of electrical conductivity of the applied displacing solution. Electrical conductivity values of the displacing solution between 0.001 and $0.93 \mathrm{dS} \cdot \mathrm{m}^{-1}$ did not affect either leachate $\mathrm{EC}$ or $\mathrm{pH}$ (Table 4). A solution EC of $16.7 \mathrm{dS} \cdot \mathrm{m}^{-1}$ was the only treatment that influenced leachate EC in this experiment; the leachate property might be influenced if a very small amount of displacing solution dripped out along the pot edge and mixed with the leachate without displacing the medium solution. By calculation, an amount of $0.8 \mathrm{~mL} 16.7 \mathrm{dS} \cdot \mathrm{m}^{-1}$ displacing solution would be sufficient to cause the raised leachate EC value $\left(0.3 \mathrm{dS} \cdot \mathrm{m}^{-1}\right.$; calculated from Table 4) in this treatment. Such a trace amount of solution would not affect the dependability of PT, because a high-EC solution would never be used for displacing in practice. Distilled water is suggested as the displacing solution for research, but for greenhouse practice, fertilizer solution and tap water are both acceptable. No matter what kind of medium is used, no research has focused on this aspect in the literature. The results of this experiment offer evidence to demonstrate the principle of PT extraction, in which the medium solution can be pressed out by a displacing solution.

Effect of leachate collection time. The first experiment investigated how soon sampling can be done after fertigation. Timing of PT sampling between 20 and 160 min after fertigation did not affect leachate EC values (Table 5). On a peat-based medium, Cavins et al. (2005) demonstrated that collecting leachate between 13 and $240 \mathrm{~min}$ after fertigation did not result in different leachate EC values. However, leachate sampled immediately after fertigation (at Minute 0) had a higher EC level than other treatments (Table 5), and this level was close to that of fertilizer EC $\left(1.32 \mathrm{dS} \cdot \mathrm{m}^{-1}\right)$. The results indicate that $\approx 20 \mathrm{~min}$ is needed for nutrient equilibration between the added fertilizer solution and the substrate. Wright (1986) suggested doing the sampling $1 \mathrm{~h}$ after fertigation; this suggestion is also valid for sphagnum moss in 10.5 -cm pots according to our data as shown in Table 5 .

The follow-up experiments were designed to determine how long the sampling can be
Table 5. Leachate electrical conductivity (EC) and $\mathrm{pH}$ of sphagnum moss as affected by leachate collection time after fertigation.

\begin{tabular}{ccl}
\hline $\begin{array}{c}\text { Collection } \\
\text { time }(\mathrm{min})\end{array}$ & $\begin{array}{c}\text { Leachate EC } \\
\left(\mathrm{dS} \cdot \mathrm{m}^{-1}\right)\end{array}$ & $\begin{array}{c}\text { Leachate } \\
\mathrm{pH}\end{array}$ \\
\hline 0 & $1.22 \mathrm{a}^{\mathrm{y}}$ & $3.46 \mathrm{bcd}^{\mathrm{z}}$ \\
20 & $1.05 \mathrm{~b}$ & $3.68 \mathrm{ab}$ \\
40 & $1.00 \mathrm{~b}$ & $3.64 \mathrm{abc}$ \\
60 & $1.06 \mathrm{~b}$ & $3.56 \mathrm{abcd}$ \\
80 & $0.98 \mathrm{~b}$ & $3.65 \mathrm{abc}$ \\
100 & $1.03 \mathrm{~b}$ & $3.74 \mathrm{a}$ \\
120 & $0.99 \mathrm{~b}$ & $3.62 \mathrm{abcd}$ \\
140 & $1.05 \mathrm{~b}$ & $3.43 \mathrm{~cd}$ \\
160 & $1.00 \mathrm{~b}$ & $3.40 \mathrm{~d}$ \\
\hline
\end{tabular}

${ }^{\mathrm{z}}$ Means in the same column followed by a different letter are significantly different at $P \leq 0.05$ by least significant difference test $(n=20)$.

delayed. Leachate EC levels showed no significant difference between treatments of sampling time from 0 to $6 \mathrm{~d}$ (Expt. 1) and 0 to $10 \mathrm{~d}$ (Expt. 2) after fertigation, but decreased after Day 10 (Table 6). Leachate $\mathrm{pH}$ fluctuated from 3.0 to 3.7 within the $25 \mathrm{~d}$ and showed no correlation to the timing of leachate collection (Table 6). For practical application, collecting leachate within $24 \mathrm{~h}$ after fertigation is acceptable. The results also demonstrated the unique characteristic of sphagnum moss for retaining water for up to 3 weeks. During the long-term monitoring by PT, we can see the decreasing trend of substrate EC with time (Table 6). The slight decrease of leachate EC is apparently caused by nutrient uptake by roots of Phalaenopsis.

Changes of leachate $\mathrm{pH}$ values. The $\mathrm{pH}$ values of the medium solution determined in the experiments ranged mostly between 3 and 4 (Tables 1-6). Most of the tested $\mathrm{pH}$ values fluctuated and did not show specific trends with treatments, but they usually were in a range differing only by 0.2 units within each experiment. The main factor affecting the $\mathrm{pH}$ value of the substrate was unlikely to be the treatments such as the volume of displacing water and the quality of displacing water, but more likely to be the result of the cultivation duration. We can see in Table 4 that when applying a pH 7.48 tap water or a pH 6.48200 $\mathrm{mg} \cdot \mathrm{L}^{-1} \mathrm{~N}$ fertilizer solution as displacing water, collected leachate remained in the range of $\mathrm{pH} 3$ to 4 . The experiment with the result shown in Table 3 had the lowest $\mathrm{pH}$ value among all the experiments discussed, and it coincided with the use of plants that 
had been grown for 2 months. When cultivating Phalaenopsis with bark, leachate $\mathrm{pH}$ decreased from 6.9 to 5.8 in a 10-month experimental period (Wang, 1998), but the acidity of the substrate was closer to the ideal range $(\mathrm{pH} 5.4$ to 6.0) for nutrition uptake of plants in soilless medium (Nelson, 2003). Growing Phalaenopsis in sphagnum moss tended to result in a low substrate $\mathrm{pH}$. The original $\mathrm{pH}$ of sphagnum moss was $\approx 5$ after water immersion and before transplanting. Because the $\mathrm{pH}$ value decreased with cultivation time, it is possible that the decomposition of sphagnum moss and the $\mathrm{H}^{+}$ release from Phalaenopsis roots resulting from nutrition uptake (Mengel and Kirkby, 2001) may be the causes for the substrate acidification.

Comparison of substrate electrical conductivity as tested by pour-through and by press. The substrate EC levels obtained by PT and PE were highly correlated with high correlation coefficients for the two methods ( $r=0.97$; Fig. 1). The EC level measured by PT extraction was about the same level as

Table 6. Leachate electrical conductivity (EC) and $\mathrm{pH}$ of sphagnum moss as affected by multiday delay collection time after fertigation.

\begin{tabular}{lcc}
\hline $\begin{array}{l}\text { Collection } \\
\text { time (d) }\end{array}$ & $\begin{array}{c}\text { Leachate EC } \\
\left(\mathrm{dS} \cdot \mathrm{m}^{-1}\right)\end{array}$ & $\begin{array}{c}\text { Leachate } \\
\mathrm{pH}\end{array}$ \\
\hline & $\begin{array}{c}\text { Expt. } 1 \\
0\end{array}$ & $3.41 \mathrm{c}$ \\
1 & $0.64 \mathrm{a}^{\mathrm{z}}$ & $3.73 \mathrm{a}$ \\
2 & $0.63 \mathrm{a}$ & $3.70 \mathrm{a}$ \\
3 & $0.63 \mathrm{a}$ & $3.59 \mathrm{~b}$ \\
4 & $0.64 \mathrm{a}$ & $3.64 \mathrm{ab}$ \\
5 & $0.65 \mathrm{a}$ & $3.66 \mathrm{ab}$ \\
6 & $0.65 \mathrm{a}$ & $3.65 \mathrm{ab}$ \\
& $0.65 \mathrm{a}$ & \\
0 & Expt. 2 & $3.43 \mathrm{a}$ \\
5 & $0.66 \mathrm{a}$ & $2.96 \mathrm{c}$ \\
10 & $0.65 \mathrm{ab}$ & $3.36 \mathrm{a}$ \\
15 & $0.63 \mathrm{ab}$ & $3.40 \mathrm{a}$ \\
20 & $0.60 \mathrm{bc}$ & $3.22 \mathrm{~b}$ \\
25 & $0.55 \mathrm{~cd}$ & $2.97 \mathrm{c}$ \\
\hline
\end{tabular}

${ }^{\mathrm{z}}$ Means in the same column followed by a different letter are significantly different at $P \leq 0.05$ by least significant difference test $(\mathrm{n}=20)$.

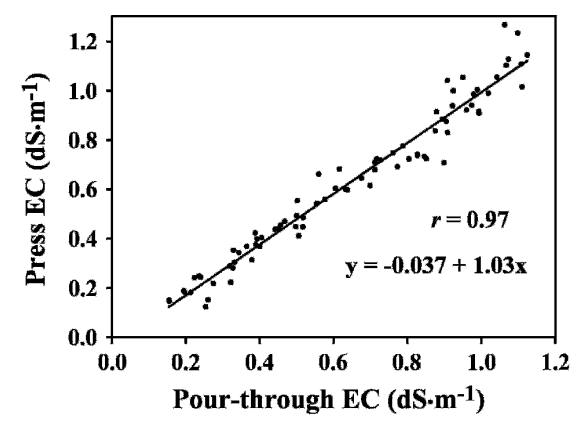

Fig. 1. Relationship between substrate electrical conductivity (EC) tested by pour-through and by the press method. The EC of fertilizer solutions applied ranged from 0 to $1.6 \mathrm{dS} \cdot \mathrm{m}^{-1}$. that by the PE method when the tested substrate EC levels ranged from 0.2 to $1.1 \mathrm{dS} \cdot \mathrm{m}^{-1}$. Compared with the EC levels (from 0 to $1.6 \mathrm{dS} \cdot \mathrm{m}^{-1}$ ) of the fertilizer solutions provided in the experiment, leachate EC was a little higher than fertilizer EC when fertilizer concentrations were low, but much lower when higher concentrations of fertilizer were applied (Fig. 1). The result indicates that fresh sphagnum moss has a strong buffer capacity so that some levels of nutrients were held by the substrate and could therefore not be extracted either by PE or PT. Those adsorbed nutrients could be labile and released back to the medium solution when the amount of fertilizer applied is low.

High correlation coefficients between the EC levels obtained by PT and SME on peat-based medium and bark-based medium demonstrated PT to be a reliable medium testing method (Cavins et al., 2004; Yeager et al., 1983). Although there is a concern that the high porosity of sphagnum moss might affect the feasibility of PT, the observation that substrate EC tested by PT resembles the result of $\mathrm{PE}$ is proof for the effectiveness of PT applied to sphagnum moss (Fig. 1). Press is an extraction method for plugs that emphasizes solution displacement without significant dilution (Scoggins et al., 2001). Extraction results obtained by $\mathrm{PE}$ are highly correlated with that by SME on peat-based medium (Scoggins et al., 2002). By squeezing out the equilibrated medium solution for testing, PE could be the best medium extraction method to present the authentic rhizosphere status. However, the disadvantages of applying PE on Phalaenopsis cultivation are that the substrate is compacted by press and hence some roots may be damaged. Results of the experiment demonstrate that PT and PE are both comparable for obtaining medium solution from a sphagnum-based growing medium. The benefit of using PT is that the medium and roots remain intact.

This study validates that the PT method, extracting medium solution at container capacity by displacement, can be applied to Phalaenopsis grown with sphagnum moss. The suggested procedure for a $10.5-\mathrm{cm}$ pot is to apply $60 \mathrm{~mL}$ distilled water slowly to the surface of the substrate $1 \mathrm{~h}$ after fertigation, collect the leachate, and do related analysis. Pour-through is a convenient and reliable testing method, but further research should be carried out to establish the optimum EC range required for vigorous growth of $\mathrm{Pha}$ laenopsis and other orchids grown with sphagnum moss. It should also be noted that the validation of PT on sphagnum moss was based on a commonly used bulk density, $\approx 50$ $\mathrm{mg} \cdot \mathrm{cm}^{-3}$, for Phalaenopsis planting. Further experiments may be needed when applying PT to a crop grown in sphagnum moss with a lower bulk density.

\section{Literature Cited}

Bunt, A.C. 1986. Problems in the analysis of organic and lightweight potting substrates. HortScience 21:229-231.

Cavins, T.J., B.E. Whipker, and W.C. Fonteno. 2004. Establishment of calibration curves for comparing pour-through and saturated media extract nutrient values. HortScience 39:1635-1639.

Cavins, T.J., B.E. Whipker, and W.C. Fonteno. 2005. Timing of pourthru affects $\mathrm{pH}$, electrical conductivity, and leachate volume. Commun. Soil Sci. Plant Anal. 36:1573-1581.

Hwang, S.J. and B.R. Jeong. 2007. Growth of Phalaenopsis plants in five different potting media. J. Jpn. Soc. Hort. Sci. 76:319-326.

Kubota, S., T. Kato, and K. Yoneda. 1993. The effects of the concentration of fertilizer application and the physico-chemical properties of sphagnum moss and clay pots on the growth of Phalaenopsis. J. Jpn. Soc. Hort. Sci. 63:601-609.

Mengel, K. and E.A. Kirkby. 2001. Principles of plant nutrition. 5th Ed. Kluwer Academic Publishers, Dordrecht, The Netherlands.

Murphy, J. and J.P. Riley. 1962. A modified single solution method for the determination of phosphorus in natural water. Anal. Chim. Acta. 27: $31-36$.

Nelson, P.V. 2003. Greenhouse operations and management. 6th Ed. Prentice Hall, Upper Saddle River, NJ.

Page, A.L., R.H. Miller, and D.R. Keeney. 1986. Methods of soil analysis. 2nd Ed. American Society of Agronomy, Madison, WI.

Puustjarvi, V. 1977. Peat and its use in horticulture. Turveteollisuusliitto, Helsinki, Finland.

Scoggins, H.L., D.A. Bailey, and P.V. Nelson. 2001. Development of the press extraction method for plug substrate analysis: Quantitative relationships between solution extraction techniques. HortScience 36:918-921.

Scoggins, H.L., D.A. Bailey, and P.V. Nelson. 2002. Efficacy of the press extraction method for bedding plant plug nutrient monitoring. HortScience 37:108-112.

Sonneveld, C. 1990. Estimating quantities of water-soluble nutrients in soils using a specific $1: 2$ by volume extract. Commun. Soil Sci. Plant Anal. 21:1257-1265.

Tolman, D.A., A.X. Niemiera, and R.D. Wright. 1990. Influence of plant age on nutrient absorption for marigold seedlings. HortScience 25:1612-1613.

Wang, Y.T. 1998. Impact of salinity and media on growth and flowering of a hybrid Phalaenopsis orchid. HortScience 33:247-250.

Warncke, D.D. 1986. Analyzing greenhouse growth media by the saturation extraction method. HortScience 21:223-225.

Wright, R.D. 1986. The pour-through nutrient extraction method procedure. HortScience 21: 227-229.

Wright, R.D., K.L. Grueber, and C. Leda. 1990 Medium nutrient extraction with the pourthrough and saturated medium extract procedures for poinsettia. HortScience 25:658-660.

Wright, R.D. and L.E. Hinesley. 1991. Growth of containerized eastern redcedar amended with dolomitic limestone and micronutrients. HortScience 26:143-145.

Yeager, T.H., R.D. Wright, and S.J. Donohue. 1983. Comparison of pour-through and saturated pine bark extract $\mathrm{N}, \mathrm{P}, \mathrm{K}$, and $\mathrm{pH}$ levels. J. Amer. Soc. Hort. Sci. 108:112-114. 